\title{
THE SURFACE TOPOGRAPHY OF LARGE ICE MASSES FROM LANDSAT IMAGERY
}

\author{
By Julian A. DOWDESWElL* \\ (Scott Polar Research Institute, University of Cambridge, Cambridge CB2 1ER, Engiand) \\ and NEIL F. MCINTYRE \\ (Mullard Space Science Laboratory, University College London, Holmbury St. Mary, \\ Surrey RH5 6KT, England)
}

ABSTRACT. Apparent ice-surface topography is observed at several scales on Landsat multi-spectral scanner (MSS) imagery. Digitally enhanced MSS scenes from Antarctica and Nordaustlandet, Svalbard, are compared with ice-surface elevations from aircraft altimetry (relative accuracy $2-3 \mathrm{~m}$ ) to show that this apparent topography is real. Apparent ice divides on Landsat images fit closely with divides on altimetric records. Ice-surface irregularities within drainage basins are also shown to be real. On Byrd Glacier, Antarctica, apparent "flow lines" coincide with ridges on altimetric records. Synoptic Landsat data, calibrated by information from aircraft altimetric flight lines, are used to classify the surface roughness of the ice caps on Nordaustlandet and $40 \%$ of the Antarctic ice sheet. On Nordaustlandet, the roughest ice is of amplitude $15-25 \mathrm{~m}$ and wavelength $3-4.5 \mathrm{~km}$. Drainage basins with such rough surface characteristics may be associated with ice streams or possibly past surge activity. The most rough Antarctic terrain is up to $60 \mathrm{~m}$ in amplitude, with wavelengths of $<10 \mathrm{~km}$. The roughness of the Antarctic ice sheet increases with distance from ice divides, reflecting changes in the parameters affecting the transfer of basal stresses to the ice surface.

\section{INTRODUCTION}

In the often poorly mapped polar regions, the $34000 \mathrm{~km}^{2}$ synoptic view from Landsat multi-spectral scanner (MSS) data provides important glaciological information on the dimensions and form of ice masses. Apparent ice-surface ridges and undulations, illustrated in a scene covering the ice caps of Nordaustlandet in Svalbard (Fig. 1), are typical of the detail which can be achieved (Swithinbank and Lucchitta, 1986). Several workers have interpreted features similar to the apparent ridges in Figure 1 as ice divides (e.g. Thorarinson and others, 1973; Holdsworth, 1977). A comparison between surveyed surface elevations and Landsat imagery of the Gipps Ice Rise, Antarctica, found that such apparent ridges did coincide with ice divides on the ground (Martin and Sanderson, 1980 ) but that they were not marked by discrete ridges. The purpose of this paper is to demonstrate that the apparent topography observed at several scales on Landsat images of large ice masses is real. This is achieved by comparison of Landsat imagery and aircraft altimetry. The Antarctic ice sheet and the ice caps on Nordaustlandet, Svalbard, were selected for study (Fig. 2), to illustrate the different patterns of ice-surface topography found at these differing spatial scales.

*Present address: Department of Geography, University College of Wales, Aberystwyth, Penglais, Aberystwyth, Dyfed SY23 3DB, Wales.
The presence of apparent ice-surface topography on Landsat imagery cannot be a result of direct shadowing, for a combination of two reasons. First, very low surface-slope angles characterize the centre of large ice masses, and slopes of less than $2^{\circ}$ are typically present over most of Antarctica and the ice caps of Nordaustlandet (Dowdeswell and McIntyre, 1986). Secondly, Landsat imagery is not normally collected when sun elevation is less than $10^{\circ}$ above the horizontal (U.S. Geological Survey, 1979). If direct shadowing is not a cause of these variations in radiance, the implication is that such snow-covered ice-mass surfaces do not behave as Lambert's law reflectors (i.e. they do not reflect energy equally in all directions). Work by Dowdeswell and McIntyre (1986) indicates that it is the angle of sun incidence relative to the slope of the ice surface that is the primary factor affecting radiance from the snow-covered surfaces of large ice masses. Martin and Sanderson (1980) have also suggested that differences in the reflective properties of snow on either side of ice divides may be related to changes in crystal orientation, but the necessary field data to test this hypothesis are not available.

\section{DATA SOURCES AND METHODS}

Digital data from the Landsat MSS were selected to cover the study areas in Svalbard and Antarctica (Fig. 2). Image processing and digital enhancement of Landsat computer-compatible tapes (CCTs) was carried out on a GEMS Image Display System at the National Remote Sensing Centre, Royal Aircraft Establishment, Farnborough, England. The enhancement of digital MSS data is particularly important over ice masses, because electromagnetic reflections from snow and ice are often spread over only a few brightness levels close to the upper calibration limit of the detectors. Indeed, when sun elevation above the horizon is relatively high, some MSS bands may become saturated. This leads to a loss of signal, occurring most frequently in band 5 (known as band 2 for Landsats 4 and 5) of the MSS (Dowdeswell and McIntyre, 1986). Detector saturation only occurs, however, in very limited areas of the scenes analysed in this study.

Data for validating the apparent ice-surface detail observed on Landsat imagery were available in the form of aircraft radar altimetry over Antarctica and Svalbard. Simultaneous records of terrain clearance $\left(R_{\mathrm{a}}\right)$ and aircraft pressure altitude $\left(P_{\mathrm{a}}\right)$ enabled the determination of ice-surface elevations along flight lines. Thus:

$$
S_{\mathrm{a}}=P_{\mathrm{a}} R_{\mathrm{a}}
$$

where $S_{\mathrm{a}}$ is surface elevation. The accuracy of absolute altitudes is dependent on the temporal and spatial stability of pressure surfaces, variations of which are associated with weather systems. To limit errors, analysis was restricted to 


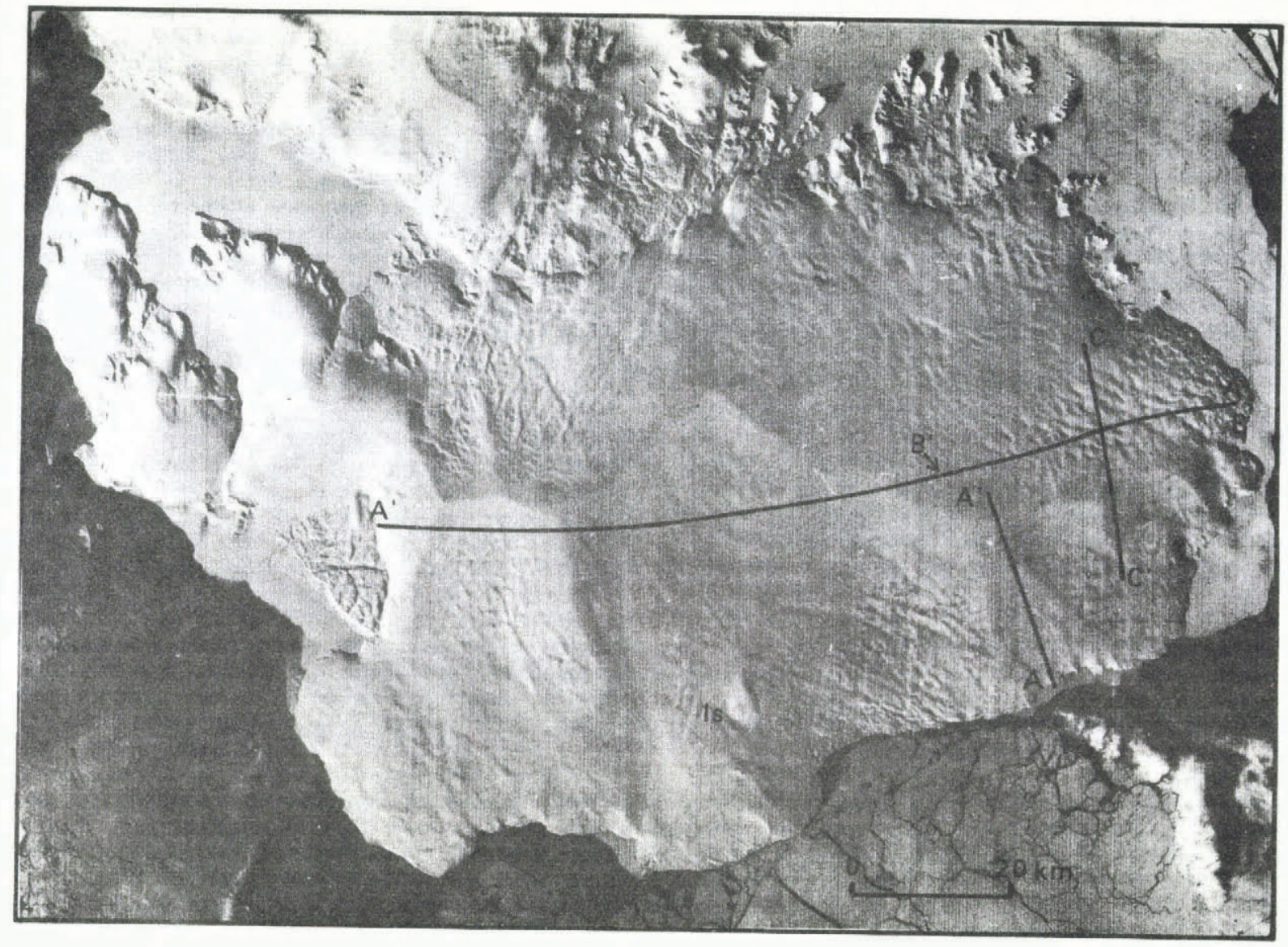

Fig. 1. MSS band 7 scene for 25 March 1973 (Id. 124511580) showing apparent ridges (ice divides) and smaller-scale undulations within drainage basins on Austfonna, Nordaustlandet. Svalbard. The feature marked "Is" is a small ice dome. Altimetric transects from Figures 3 and 4 are included.

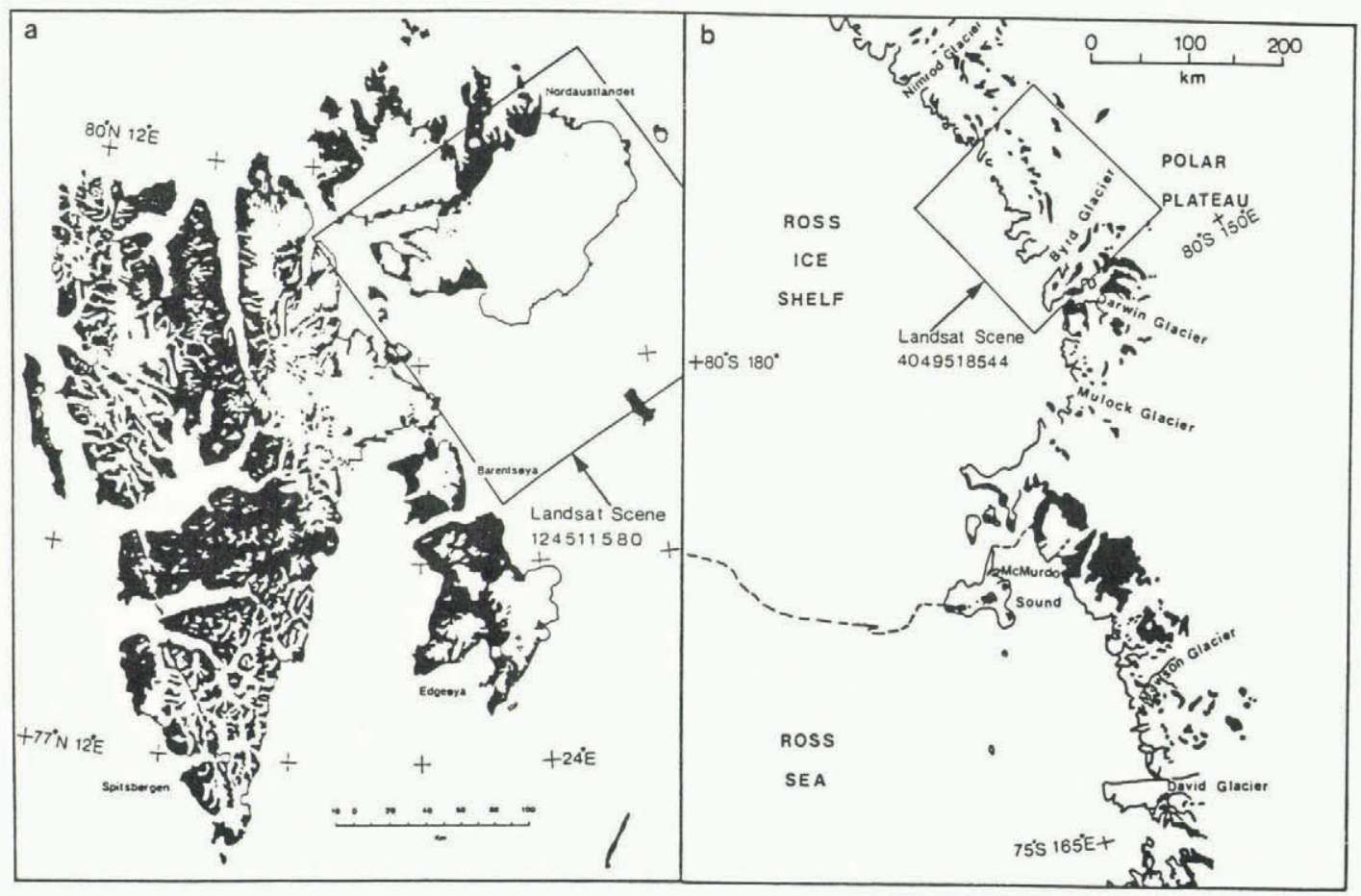

Fig. 2. Maps of the study areas: (a) The ice caps on Nordaustlandet, Svalbard; (b) Byrd Glacier and the Ross Ice Shelf, Antarctica. The Landsat images from which the sub-scenes in Figures 1 and 5 are taken are shown. 
relatively short flight sections (less than about $200 \mathrm{~km}$ ) and altimetric data were usually used to calculate only relative surface elevations.

The Antarctic altimetric data were collected in 1979 during a radio echo-sounding programme run jointly by the U.S. National Science Foundation, the Scott Polar Research Institute (SPRI), and the Technical University of Denmark. Terrain clearances were determined by a $4.3 \mathrm{GHz}$ radar altimeter which typically had a footprint $400 \mathrm{~m}$ in diameter. Elevations were derived at $25 \mathrm{~m}$ intervals along track with a relative accuracy of $2 \mathrm{~m}$ over distances of less than 150-200 km (McIntyre, unpublished). Cumulative groundtrack navigation errors could amount to $5 \mathrm{~km}$ in Antarctic flights but near identifiable features of known location this was reduced significantly (Drewry and others, 1982).

Altimetric data over Nordaustlandet, Svalbard, were collected during a joint programme of radio echo-sounding and survey work carried out by the SPRI and the Norsk Polarinstitutt in the spring of 1983. A SPRI Mk IV radio echo-sounder operating at $60 \mathrm{MHz}$ provided aircraft terrainclearance data at approximately $115 \mathrm{~m}$ intervals along track to a relative accuracy of $2 \mathrm{~m}$. The sounder illuminated an area approximately $500 \mathrm{~m}$ across at the terrain clearances flown. Navigation was accurate to better than $250 \mathrm{~m}$ throughout, and was approximately $30 \mathrm{~m}$ in the central part of Austfonna (Dowdeswell and others, 1986).

\section{COMPARISON OF LANDSAT IMAGERY AND AIRCRAFT ALTIMETRY}

The use of Landsat imagery in the description and analysis of ice-surface topography is examined at two scales: those of, (1) ice-mass drainage basins and divides, (2) undulations, flow lines and other ice-surface irregularities within basins.

\section{Ice divides}

Dowdeswell and Cooper (1986) mapped ice divides on the ice caps of Nordaustlandet from the apparent ridges visible on Landsat MSS images. We now compare the location of several of these apparent ice divides with aircraft altimetry from a flight line across the island (Fig. 3), in order to demonstrate that these ridges do indeed represent ice divides on the ground. The apparent divides match closely (better than $0.5 \mathrm{~km}$ ) with crests determined from aircraft altimetry. The divide noted on Landsat imagery $48 \mathrm{~km}$ along the transect is less distinct than the others because the flight line intersects the crest obliquely. Figure 3 therefore shows that the apparent ridges noted on Landsat imagery of Nordaustlandet, and other large ice masses, provide an accurate indicator of the location of ice divides.

\section{Ice-surface irregularities within drainage basins}

Altimetric transects within two basins on Nordaustlandet with smooth and rough topography were selected for comparison between imagery and altimetry. The positions of surface undulations (wavelengths typically between 1 and $4 \mathrm{~km}$ ) derived from the two data sources are shown in Figure 4. The transects are also located on the Landsat images in Figure 1, which illustrates the differing character of the rougher and smoother sections. The undulations from the two data sources generally coincide to within $200-500 \mathrm{~m}$, values which subsume both aircraft navigational errors and inaccuracies in superimposing the imagery and flight lines. The relative absence of surface undulations in transect $\mathbf{A}-\mathbf{A}^{\prime}$ is apparent. The surface of Leighbreen is relatively rough both parallel $\left(B-B^{\prime}\right)$ and normal $\left(C-C^{\prime}\right)$ to the direction of ice flow. The coincidence in location between undulations recorded from Landsat and aircraft altimetric data indicates that Landsat imagery may be used to classify the ice-cap surface in terms of its roughness.

Both imagery and altimetry from the region of converging ice flow where Byrd Glacier cuts through the Transantarctic Mountains (lat. $80.5^{\circ} \mathrm{S}$., long. $155^{\circ} \mathrm{E}$.) are shown in Figure 5. Features of the ice-sheet surface clearly visible on the Landsat image include bands of both heavily and less heavily crevassed ice and apparent flow lines and undulations. The apparent topography of the ice surface shown in the scene is confirmed in many cases along the flight line by coincidence with ridges and crests derived from altimetry. The correlation is generally better than $500 \mathrm{~m}$, which is well within the likely cumulative errors in navigation and superimposition of the two sources. There are some features on the Landsat image which it is not easy to correlate with the altimetry. These are generally associated with textural and tonal variations which could be attributable to crevassing and variations in the character of the snow surface. Of the distinct features in the profile in Figure 5, a band of crevassing which forms a ridge of amplitude about $7 \mathrm{~m}$ is seen at $11 \mathrm{~km}$ along the transect. Other features correspond to flow lines, which Crabtree and Doake (1980) suggested may be "gently undulating ridges and troughs". The flow line at about $42 \mathrm{~km}$ along the transect in Figure 5 has a peak-to-trough amplitude of

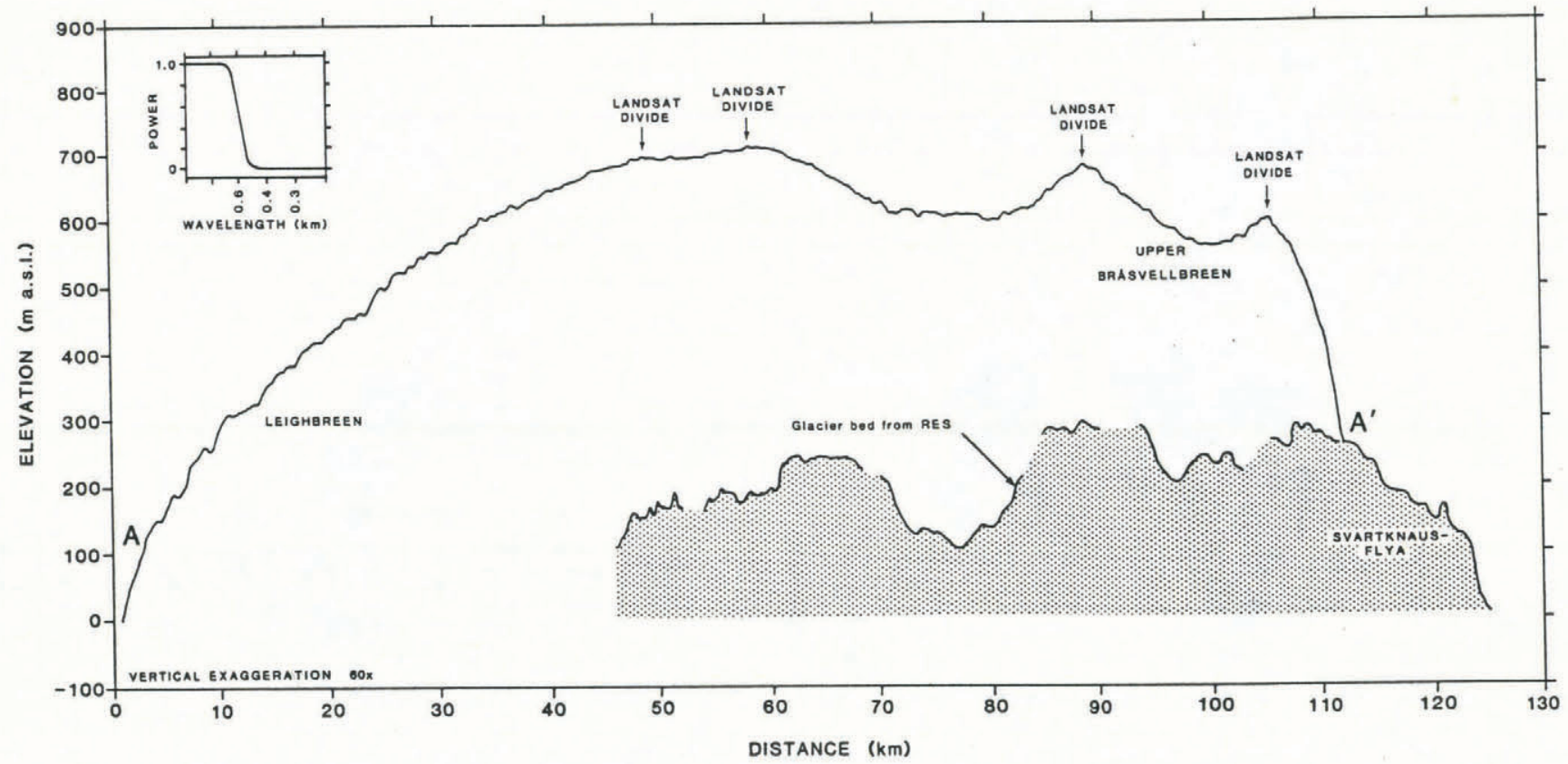

Fir. 3. Comparison of the location of ice divides from Landsat imagery and aircraft altimetry. Inset is the response of the low-pass filter applied to the altimetric data. The profile $\mathrm{A}^{-} \mathrm{A}^{\prime}$ runs from right to left in Figure 1. Vertical scale is exaggerated by a factor of 60 . 


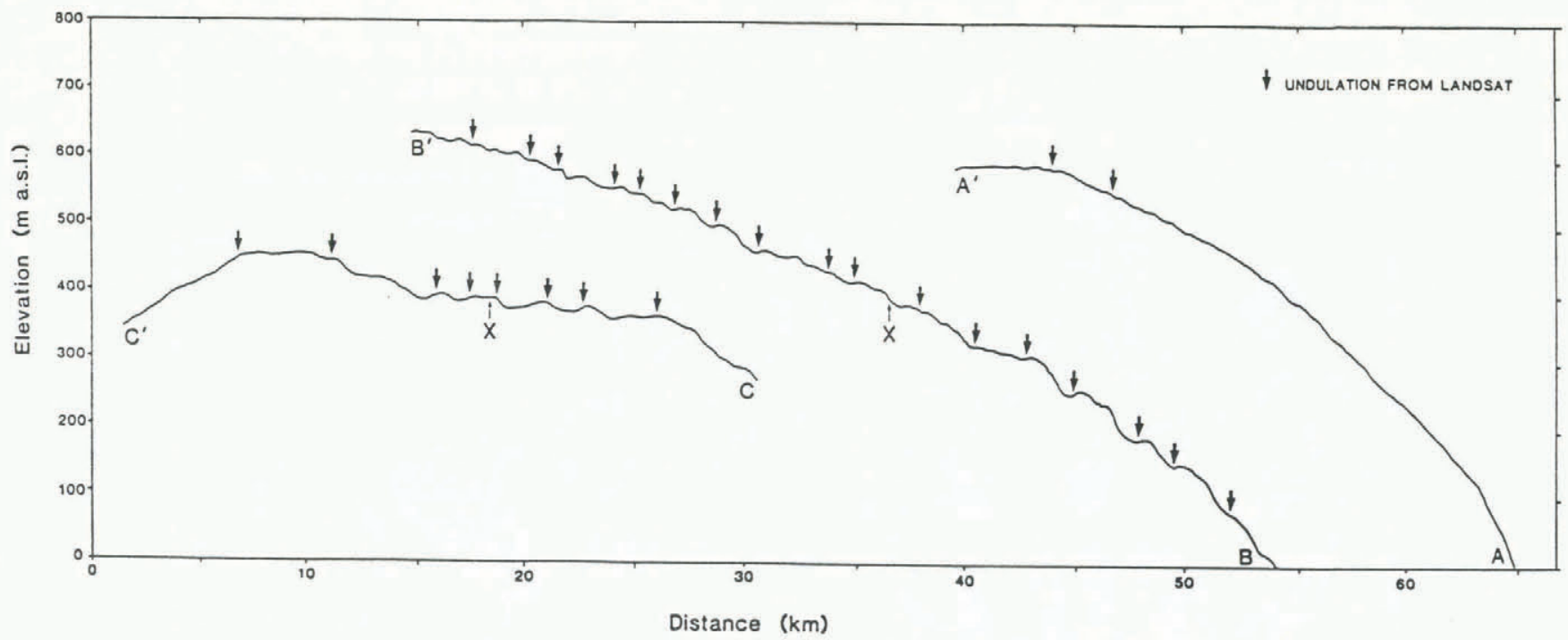

Fig. 4. Ice-surface topography along three flight lines within relatively smooth $\left(\mathbf{A}-\mathrm{A}^{\prime}\right)$ and rough $\left(\mathrm{B}^{-} \mathrm{B}^{\prime}\right.$ and $\mathrm{C}^{\left.-\mathrm{C}^{\prime}\right)}$ drainage basins. The flight lines are located in Figures 1 and 7 ( $\mathrm{A}^{-} \mathrm{A}^{\prime}$. and $\mathrm{B}^{-} \mathrm{B}^{\prime}$ only). Undulations identified from analysis of enhanced Landsat imagery are located on the transects. $X$ represents a point at which aircraft altimetric transects cross, with an error of $6 \mathrm{~m}$ in elevation.
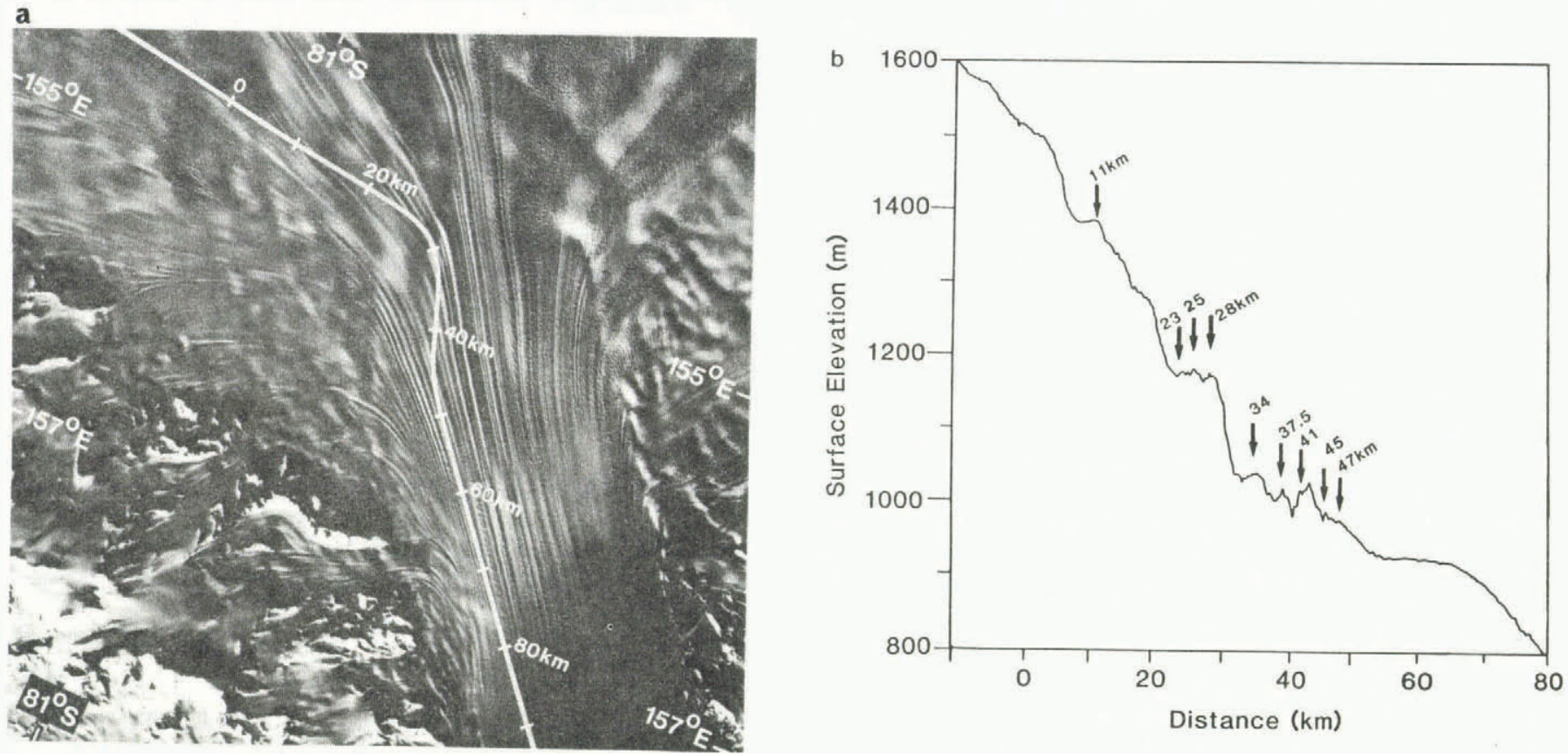

Fig. 5. Comparison of undulations and flow lines in the area of Byrd Glacier (Fig. 2) using (a) enhanced Landsat imagery (Id. 4049518544) from 24 November 1983 and (b) aircraft altimetry from January 1978. Distances along the aircraft ground track from an arbitrary origin are shown on both for comparison. Features indentified on the image are shown on the profile by arrows.

$42 \mathrm{~m}$ and a wavelength of only $4.7 \mathrm{~km}$. Others closer to the centre line of the glacier appear to have more substantial relief. Although these features are widely reported in the literature (e.g. Allison, 1979; Crabtree and Doake, 1980; Swithinbank and Lucchitta, 1986), we are not aware of any explanations as to their cause. For features of this magnitude, caused, it may be presumed, by perturbations in the flow regime rather than basal topography, substantial stresses must be involved. Their origin remains unclear.

Hughes (1977) suggested that flow through Byrd Glacier is in an unstable state and that the outlet is undergoing a surge. This has not been confirmed by repeat surveys of surface elevations in the glacier trunk (Brecher, 1982). Neither does the close correlation between features detected by Landsat imagery and aircraft altimetry obtained 6 years apart indicate the changes which might be expected from major flow perturbations. This even applies to topography down-stream of the step in the profile which marks a point of ice acceleration to velocities of from 300 to over $800 \mathrm{~m} \mathrm{a}^{-1}$ (McIntyre, 1985).

\section{ICE-SURFACE TOPOGRAPHY OF NORDAUSTLANDET}

\section{Surface topography}

The surface roughness of the ice caps on Nordaustlandet is mapped from Landsat imagery in Figure 6. The ice surface was defined as either relatively rough or smooth, on the basis of visual inspection of digitally contrast- 


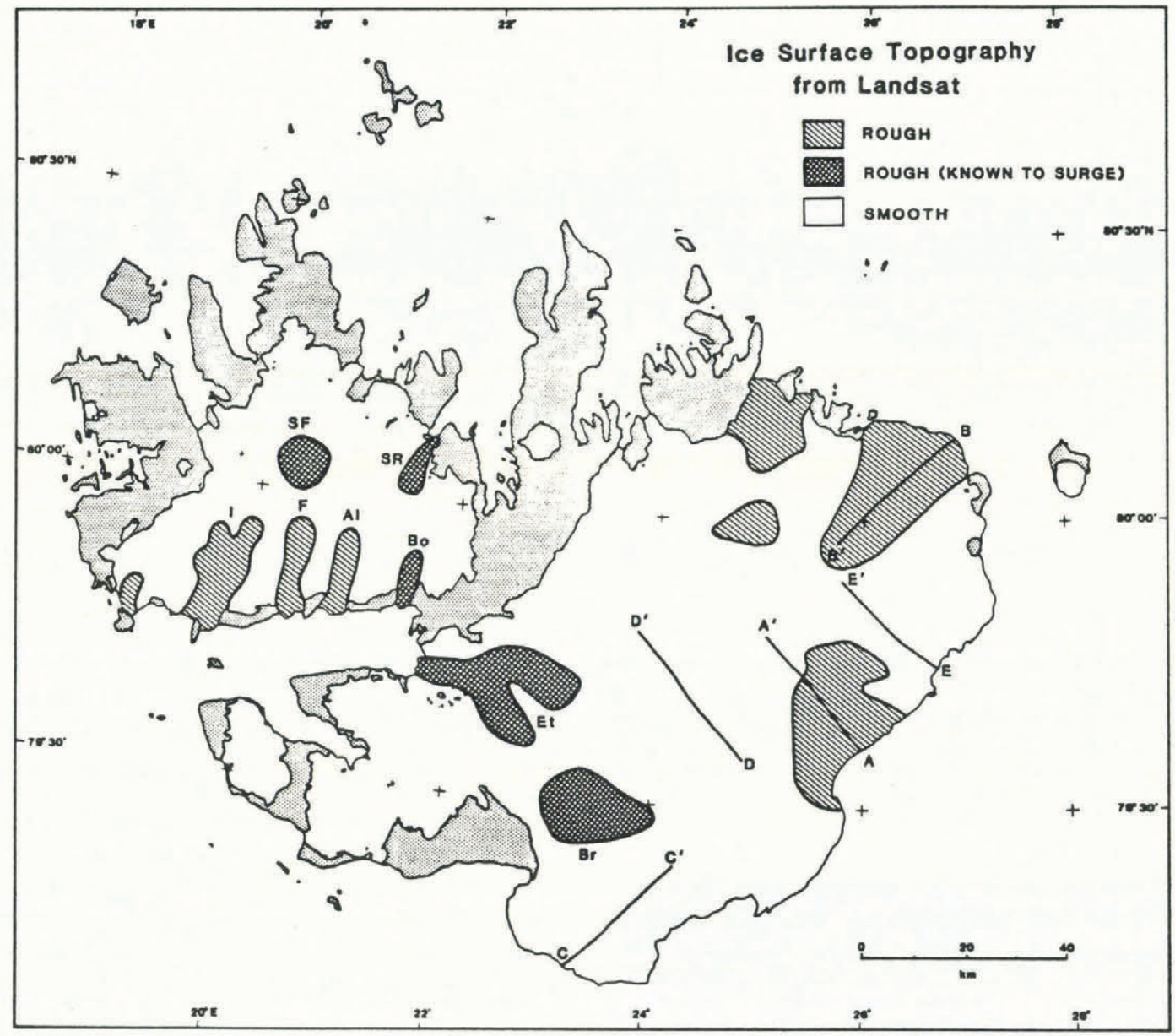

Fig. 6. Map of relative differences in ice-surface topography on Nordaustlandet from enhanced Landsat imagery. Rough areas and those which are known to have surged are shaded. The five transects in Figure 7 are shown. Letters identify drainage basins referred to in the text.

stretched Landsat imagery. Differences in topography interpreted from Landsat scenes were too small to allow any more detailed distinctions to be made. Figure 6 indicates relative differences in ice-surface morphology, but does not provide an absolute measure of roughness. Aircraft altimetric data were therefore treated using spectral analysis in order to determine the dimensions of the surface features represented in this two-group classification.

Band-pass-filtered profiles and their corresponding spectra, produced by applying a Fast Fourier Transform to five altimetric transects approximately up flow lines, are shown in Figure 7. These are used to define typical wavelengths and amplitudes for surface features in each of the two categories. The spectra and surface deviations of the two transects representative of rough parts of the ice caps $\left(A-A^{\prime}\right.$ and $\left.B-B^{\prime}\right)$ indicate that these areas are characterized by undulations of wavelength $3-4.5 \mathrm{~km}$ and amplitude 15$25 \mathrm{~m}$. The smoothest parts of the ice surface (D-D' and $\mathrm{E}-\mathrm{E}^{\prime}$ ) have amplitudes of less than $10 \mathrm{~m}$ and of ten less than $5 \mathrm{~m}$, with no marked dominant wavelength. Transect $\mathrm{c}-\mathrm{c}^{\prime}$ represents a transitional smooth area, with features of amplitude less than $10-15 \mathrm{~m}$ and relatively long wavelength undulations $(c .5 \mathrm{~km})$. Further, the energy contained in profiles of areas classified as rough and smooth varies by two orders of magnitude, and the RMS deviation of the ice surface varies from about $1.5-3.5 \mathrm{~m}$ in smooth areas to over $6 \mathrm{~m}$ for rough ice (Fig. 7).

Transect $A-A^{\prime}$ in Figure 7 includes $20 \mathrm{~km}$ of terrain classified as rough from Landsat data, and a $10 \mathrm{~km}$ smooth section. The boundary between them is relatively distinct. Due to this change in surface characteristics, the RMS deviation and spectral power of the rough section in $A-A^{\prime}$ are underestimated.

\section{Discussion}

On the ice caps of Nordaustlandet, roughness appears to differ mainly between ice-cap drainage basins (Fig. 6) Rough ice-surface topography could reflect areas of relatively thin ice, particularly in association with rough basal topography. Ice velocity (particularly sliding) may also affect the transfer function from basal to surface undulations (Hutter and others, 1981), and either steady rapid ice motion or surging (unsteady rapid ice movement) might therefore contribute to a relatively rough ice surface. Study of ice-thickness maps compiled from radio echo-sounding at $60 \mathrm{MHz}$ (Dowdeswell and others, 1986) indicates that there is no obvious correlation between rough surface topography and thin ice. Both ice caps exhibit a general decrease in thickness with approach to the coast, but on Austfonna (the larger, eastern ice mass) rough surface topography is confined to five major drainage basins, and on Vestfonna seven discrete areas of relatively rough topography are identified. Other drainage basins have relatively smooth ice surfaces (Fig. 6), even close to the coast where ice is least thick. Neither does the analysis of bedrock profiles from radio echo-sounding suggest that particularly rough bed topography is associated with basins where the ice surface is rough.

The rough areas do include, however, parts of all five of the larger outlet glaciers in Nordaustlandet that have been observed to surge (Schytt, 1969; Dowdeswell, unpublished). Of these, Bodleybreen and Søre Rijpbreen (Bo and $S R$ in Figure 6) were surging during the 1970s. However, Etonbreen (Et) and the upper parts of Bråsvellbreen $(\mathrm{Br})$ and Søre Franklinbreen (SF), which have not been observed to surge since air-photograph surveys in 1938 and 1956, remain rough (Fig. 6). A possible 

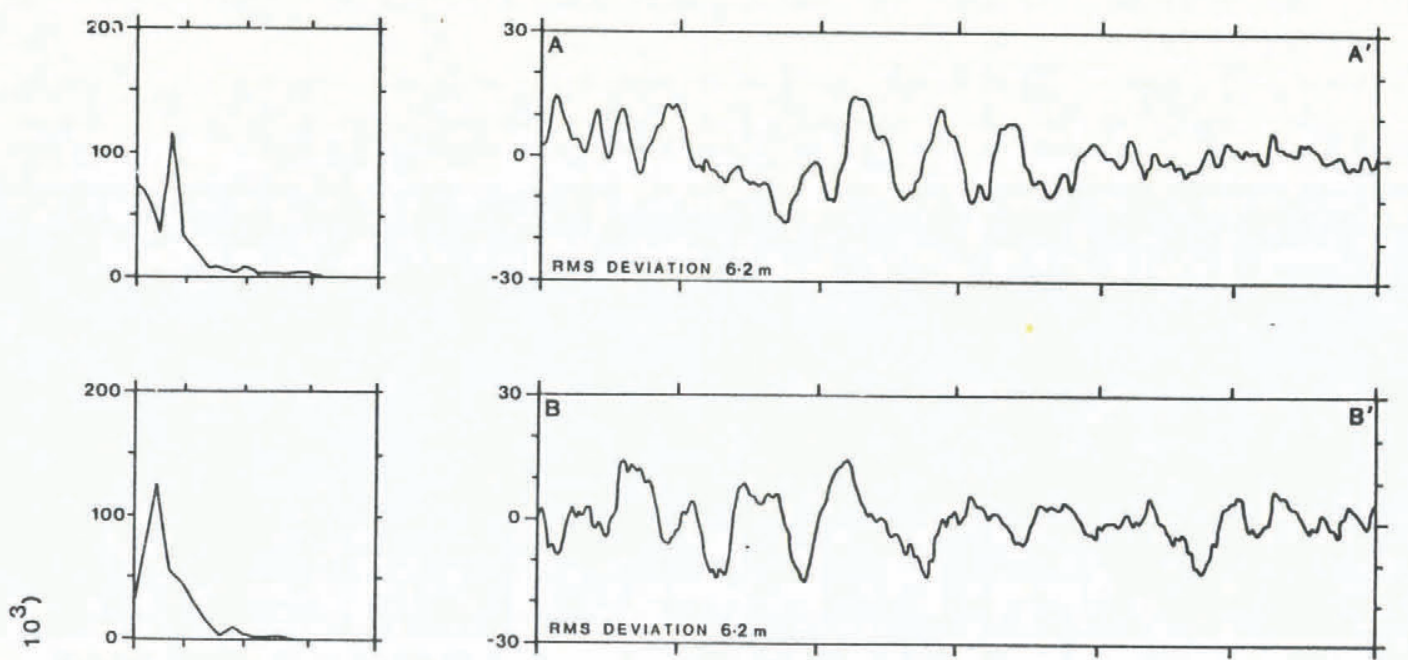

$m^{\times}$

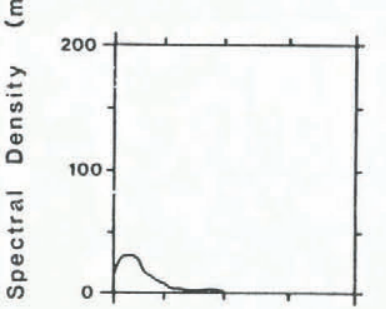

$\widehat{\underline{E}}$
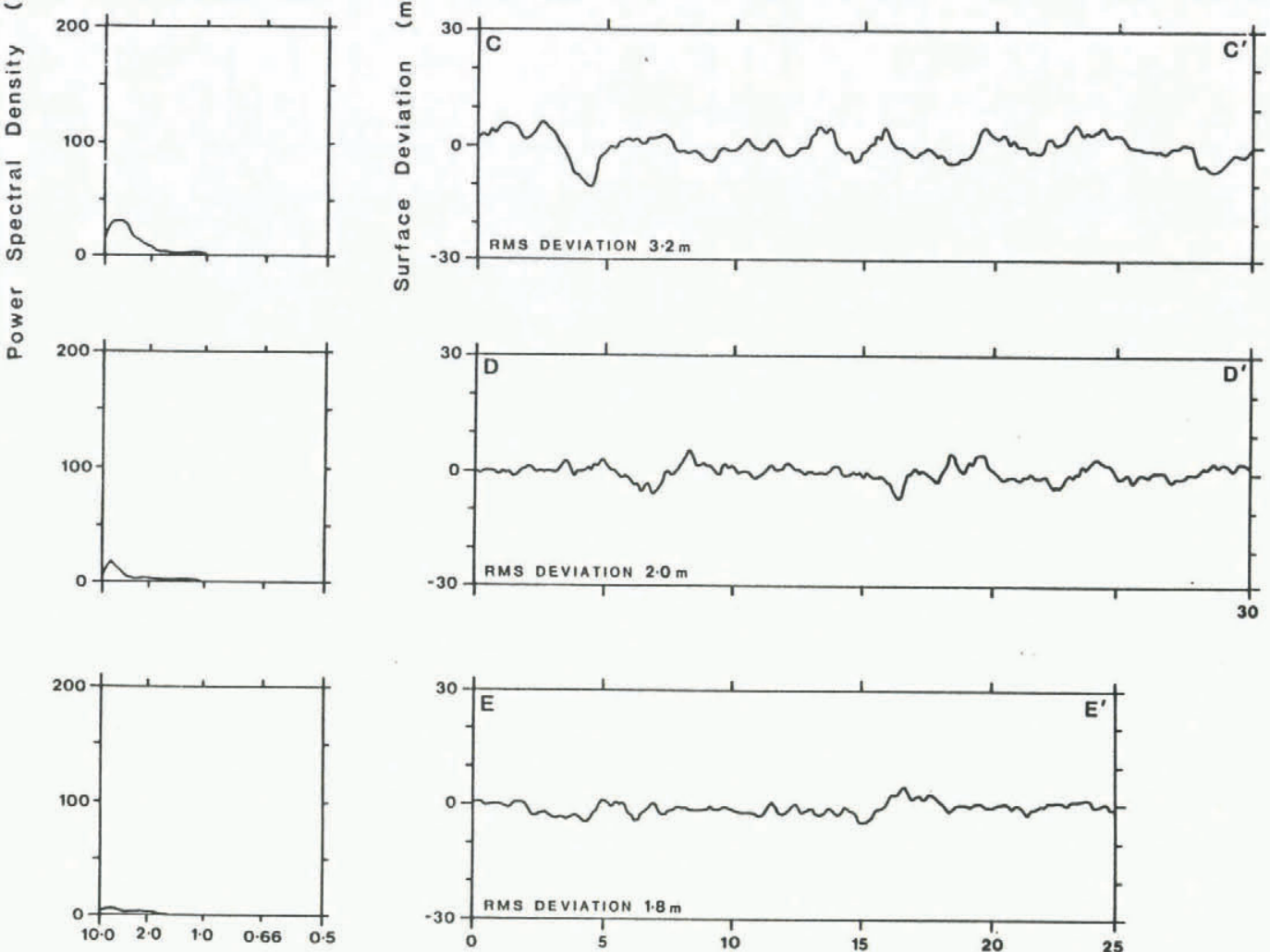

Wavelength $(\mathrm{km})$

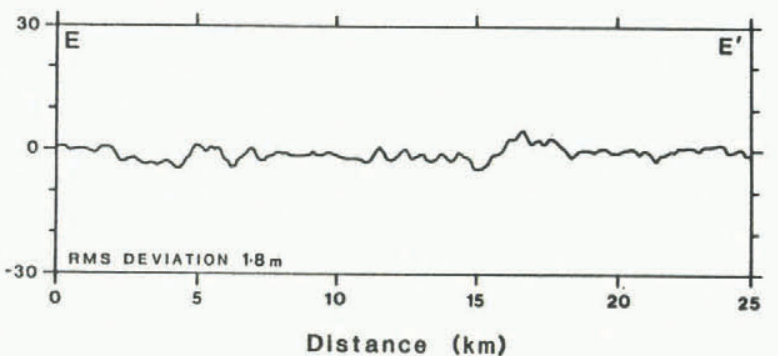

Fig. 7. Spectral power and surface deviations of aircraft altimetric data (band-pass filtered at 10 and $0.5 \mathrm{~km}$ ) from five transects located on Nordaustlandet (Fig. 6). Transects $\mathrm{A}^{-\mathrm{A}^{\prime}}$ and $\mathrm{B}-\mathrm{B}^{\prime}$ are from areas classified as rough, and the remaining three are from smooth areas. Ice flow is from right to left in all cases.

explanation for this is that a relatively rough ice surface is formed during rapid advance, and disappears only slowly when ice is relatively stagnant during the quiescent period of the surge cycle.

The outlet glaciers Aldousbreen (Al), Frazerbreen (F), and Idunbreen (I), which drain the south side of Vestfonna (Fig. 6), exhibit surface features which, although classified as rough, appear different from the other rough basins on Nordaustlandet. These well-defined linear streams of ice are between 2 and $3 \mathrm{~km}$ wide and up to $20 \mathrm{~km}$ in length, and are considerably rougher than the surrounding ice-cap surface. Inspection of air photographs, together with reports from field workers (Binney, 1925; Sandford, 1929), shows that these longitudinal features are areas of heavy crevassing which terminate abruptly at the ice-stream margins. They appear to relate to areas of the ice cap where velocity is consistently higher than on the adjacent ridges with smoother topography (Dowdeswell, 1986).

Specific discrete features observed on enhanced Landsat scenes of the surface of large ice masses are related to subglacial topography (cf. Robin, 1967). For example, the prominent, dome-shaped feature on the south-east side of Austfonna (labelled "Is" in Figure 1), was suspected to be related to a bedrock protuberance. Aircraft altimetry and radio echo-sounding confirmed both the surface form of the feature and the presence of a subglacial rise. Ice beneath the dome was less than $200 \mathrm{~m}$ thick, as compared with 300$400 \mathrm{~m}$ in thickness in the surrounding area (Dowdeswell. and others, 1986). 


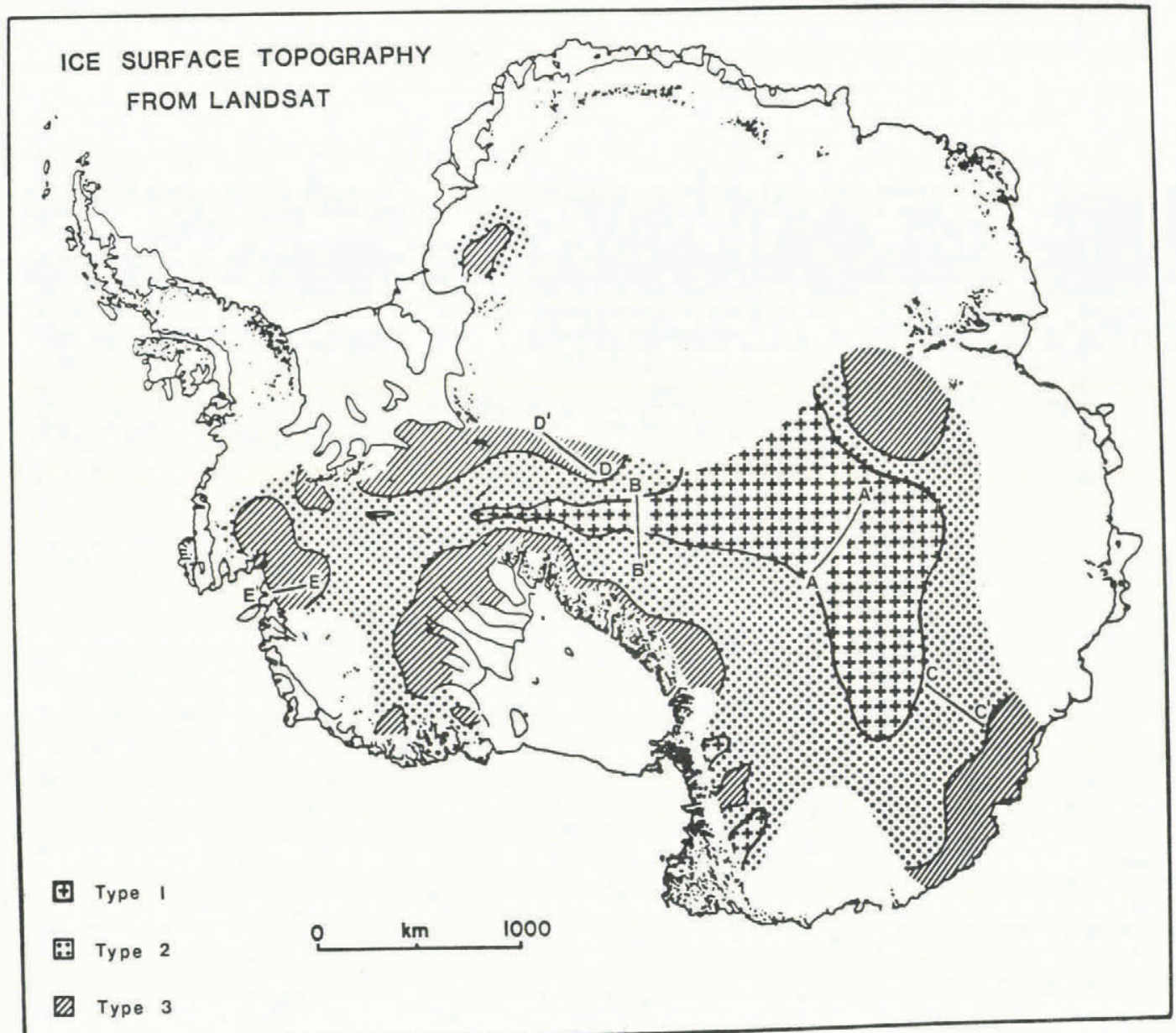

Fig. 8. Map of the relative differences in Antarctic ice-surface topography as derived from aircraft altimetry and Landsat imagery (at latitudes north of lat. $82^{\circ} \mathrm{S}$.). The five flight tracks are located in the figure. Type I terrain represents the smoothest surface topography.

\section{ICE-SURFACE TOPOGRAPHY IN ANTARCTICA}

A three-fold regional classification of the most common ice-surface morphologies (Fig. 8) has been derived from inspection of Landsat imagery and aircraft altimetric profiles over nearly $40 \%$ of the grounded part of the Antarctic ice sheet (McIntyre, unpublished). Mapping of the small-scale variability known to exist within these classes has not been attempted. In areas where there are no altimetric flight lines (Drewry, 1983), for example Coats Land, ice-surface roughness is derived from Landsat data alone. By contrast, the area south of lat. $82^{\circ} \mathrm{S}$. is outside the satellite track, and here roughness is determined through analysis of aircraft altimetry only.

Details of these terrain types have been extracted from statistical and spectral analyses of altimetry profiles. Examples of the smoothest category (type 1) are shown in Figure $9 a$ and $b$. Band-pass-filtered profiles show no deviations from the mean greater than $\pm 5 \mathrm{~m}$, with an RMS roughness of less than $1 \mathrm{~m}$. Wavelengths between 5 and $50 \mathrm{~km}$ are present, and these larger features dominate the surface. Most local gradients are less than $0.3^{\circ}$. In type 2 terrain (Fig. 9c), the planar surface is disturbed by undulations with amplitudes of up to $16 \mathrm{~m}$; the RMS roughness is typically $4-5 \mathrm{~m}$. Although wavelengths greater than $20 \mathrm{~km}$ still dominate such profiles, there is increased energy throughout the spectrum, with significant contributions at smaller wavelengths. Local surface gradients may reach $1.0^{\circ}$. Type 3 terrain (Fig. 9d and e) may display amplitudes of up to $60 \mathrm{~m}$. Power spectra of such surfaces show significant contributions over a wide range of wavelengths, and are often dominated by those less than $10 \mathrm{~km}$.
RMS roughnesses are typically $10 \mathrm{~m}$ and local slopes of $3.0^{\circ}$ may be present.

The above classification is restricted by available data coverage to an area of approximately $4.71 \times 10^{6} \mathrm{~km}^{2}$. Type 1 , type 2 , and type 3 terrain cover $1.19 \times 10^{6}, 2.49 \times 10^{6}$, and $1.03 \times 10^{6} \mathrm{~km}^{2}$, respectively. Estimation of the likely coverage for the whole continent is subject to uncertainties due to extrapolation. However, using the patterns identified in that part of the continent already mapped, it seems likely that the proportions would be approximately 20,50 , and $30 \%$ for the topographies of type 1 , type 2 , and type 3 , respectively.

The general pattern of ice-surface topographic variations in Antarctica (Fig. 8) shows an increase in roughness away from ice divides and towards the ice-sheet periphery. This distribution of ice-surface topography is related to regional changes in the variables affecting transfer to the ice surface of basal stresses induced by ice flow over bedrock undulations (e.g. Hutter and others, 1981). McIntyre (1986) discussed the interpretation of this changing pattern of Antarctic ice sheet roughness in more detail.

\section{CONCLUSIONS}

Comparison with aircraft altimetry has shown that, in the cases studied, ice-sheet surface tonal variations on Landsat images do represent real topographic variations. The use of both digitally enhanced Landsat data and aircraft altimetry to classify and describe the topographic variability found in Antarctica and Nordaustlandet demonstrates that the two data sources are complementary. Landsat imagery can be used to provide a synoptic view of the ice caps, 

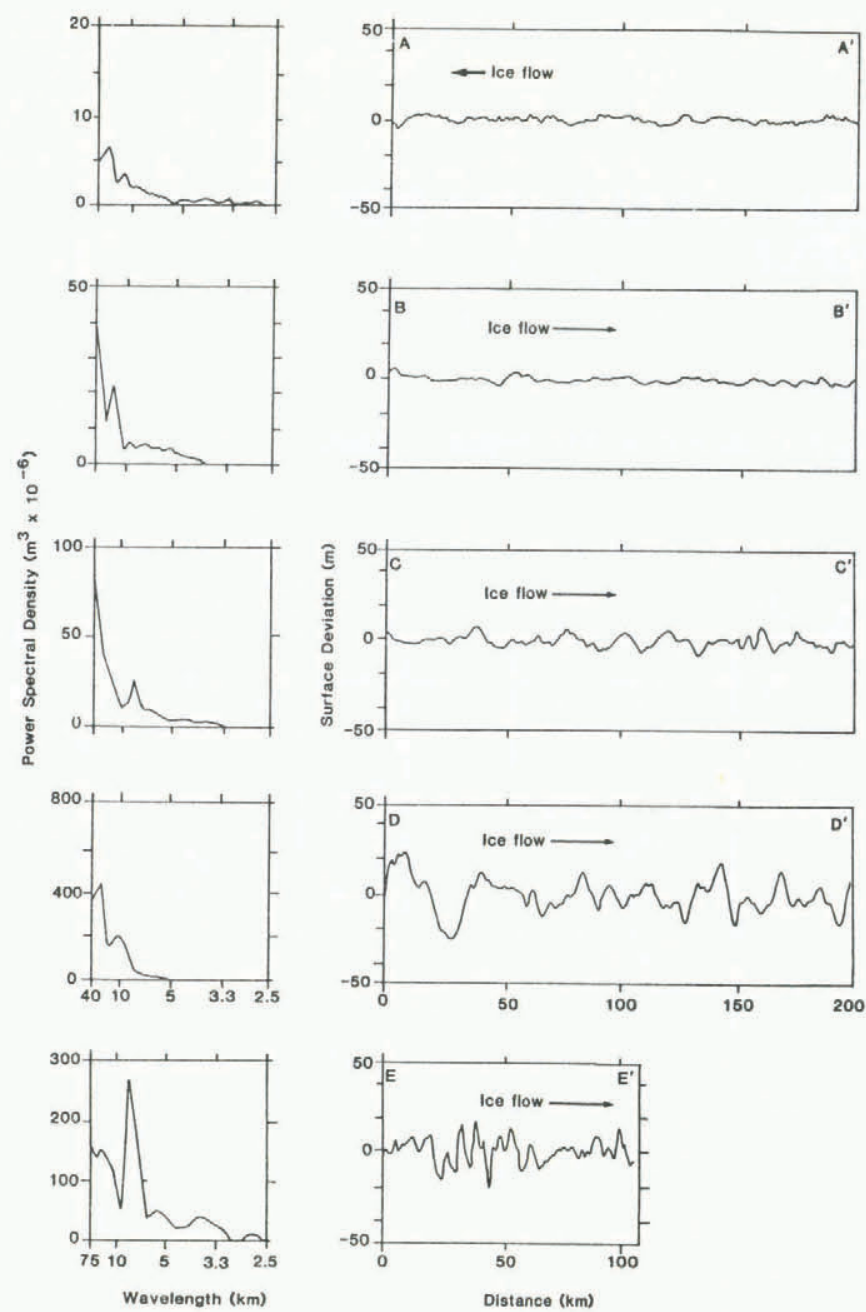

Fig. 9. Spectral power and surface deviations of aircraft altimetric data (band-pass filtered at 50 and $0.5 \mathrm{~km}$ ) from five transects located in Antarctica. $\mathrm{A}^{-\mathrm{A}^{\prime}}$ and $\mathrm{B}^{-\mathrm{B}^{\prime}}$ are from type 1 terrain; $\mathrm{C}-\mathrm{C}^{\prime}$ is from the intermediate roughness type; while $\mathrm{D}-\mathrm{D}^{\prime}$ and $\mathrm{E}-\mathrm{E}^{\prime}$ are from type 3 , the roughest topography. Flight paths are shown in Figure 8. Note the changing scale for power spectral density.

leading to a classification of large areas based on relative roughness. Analysis of aircraft altimetry, which is only available along transects, yields absolute data on the wavelength and amplitude of Landsat-derived roughness classes. A spatially restricted data set comprising absolute elevations is therefore used to calibrate the information on relative variations in surface elevation provided by synoptic satellite imagery. In Nordaustlandet, drainage basins can be identified from Landsat imagery, and basins with rough surface topography may be associated with ice streams or possibly have undergone past surge activity. On the Antarctic continent, roughness increases with approach to the ice margins, reflecting changes in the parameters affecting the transfer of basal stresses to the ice surface.

\section{ACKNOWLEDGEMENTS}

We thank the Experimental Cartography Unit of the U.K. Natural Environment Research Council (NERC) for funding to carry out digital image analysis at the National Remote Sensing Centre, Royal Aircraft Establishment, Farnborough. Much of this work was done while both authors were supported at the Scott Polar Research Institute by NERC studentships.

\section{REFERENCES}

Allison, I. 1979. The mass budget of the Lambert Glacier drainage basin, Antarctica. Journal of Glaciology, Vol. 22, No. 87 , p. 223-35.

Binney, G. [1925.] With seaplane and sledge in the Arctic. London, Hutchinson.

Brecher, H.H. 1982. Photogrammetric investigation of Byrd Glacier surface lowering. Annals of Glaciology, Vol. 3, p. 353.

Crabtree, R.D., and Doake, C.S.M. 1980. Flow-lines on Antarctic ice shelves. Polar Record, Vol. 20, No. 124, p. 31-37.

Dowdeswell, J.A. 1986. Drainage-basin characteristics of Nordaustlandet ice caps, Svalbard. Journal of Glaciology, Vol. 32 , No. 110 , p. 31-38.

Dowdeswell, J.A. Unpublished. Remote sensing studies of Svalbard glaciers. [Ph.D. thesis, University of Cambridge, 1984.]

Dowdeswell, J.A., and Cooper, A.P.R. 1986. Digital mapping in polar regions from Landsat photographic products: a case study. Annals of Glaciology, Vol. 8, p. 47-50.

Dowdeswell, J.A., and McIntyre, N.F. 1986. The saturation of LANDSAT MSS detectors over large ice masses. International Journal of Remote Sensing, Vol. 7, No. 1, p. 151-64.

Dowdeswell, J.A., and others. 1986. Digital mapping of the Nordaustlandet ice caps from airborne geophysical investigations, by J.A. Dowdeswell, D.J. Drewry, A.P.R. Cooper, M.R. Gorman, O. Liestøl, and O. Orheim. Annals of Glaciology, Vol. 8, p. 51-58.

Drewry, D.J., ed. 1983. Antarctica: glaciological and geophysical folio. Cambridge, University of Cambridge. Scott Polar Research Institute.

Drewry, D.J., and others. 1982. Measured properties of the Antarctic ice sheet: surface configuration, ice thickness, volume and bedrock characteristics, by D.J. Drewry, S.R. Jordan, and E. Jankowski. Annals of Glaciology, Vol. 3, p. $83-91$.

Holdsworth, G. 1977. Surge activity on the Barnes Ice Cap. Nature, Vol. 269 , No. 5629 , p. 588-90.

Hughes, T.J. 1977. West Antarctic ice streams. Reviews of Geophysics and Space Physics, Vol. 15, No. 1, p. 1-46.

Hutter, K., and others. 1981. First-order stresses and deformations in glaciers and ice sheets, by $\mathrm{K}$. Hutter, F. Legerer, and U. Spring. Journal of Glaciology, Vol. 27, No. 96 , p. $227-70$.

McIntyre, N.F. 1985. The dynamics of ice-sheet outlets. Journal of Glaciology, Vol. 31, No. 108, p. 99-107.

McIntyre, N.F. 1986. Antarctic ice-sheet topography and surface-bedrock relationships. Annals of Glaciology, Vol. 8 , p. $124-28$.

McIntyre, N.F. Unpublished. The topography and flow of the Antarctic ice sheet. [Ph.D. thesis, University of Cambridge, 1983.]

Martin, P.J., and Sanderson, T.J.O. 1980. Morphology and dynamics of ice rises. Journal of Glaciology, Vol. 25, No. 91, p. $33-45$.

Robin, G. de Q. 1967. Surface topography of ice sheets. Nature, Vol. 215, No. 5105, p. 1029-32.

Sandford, K.S. 1929. The glacial conditions and Quaternary history of North-East Land. Geographical Journal, Vol. 74 , No. 5, p. 451-70; No. 6, p. 543-52.

Schytt, V. 1969. Some comments on glacier surges in eastern Svalbard. Canadian Journal of Earth Sciences, Vol. 6, No. 4, Pt. 2, p. 867-73.

Swithinbank, C.W.M., and Lucchitta, B.K. 1986. Multispectral digital image mapping of Antarctic ice features. Annals of Glaciology, Vol. 8, p. 159-63.

Thorarinson, S., and others. 1973. ERTS-1 image of Vatnajökull: analysis of glaciological, structural, and volcanic features, by S. Thorarinson, K. Sæmundsson, and R.S. Williams, jr. Jökull, Ár 23, p. 7-17.

U.S. Geological Survey. 1979. Landsat data users handbook. Revised edition. Washington, DC, U.S. Geological Survey. 